\title{
High burden and unmet patient needs in chronic kidney disease
}

This article was published in the following Dove Press journal: International Journal of Nephrology and Renovascular Disease 12 December 2012

Number of times this article has been viewed

\section{LeeAnn Braun' \\ Vipan Sood ${ }^{2}$ \\ Susan Hogue' \\ Bonnie Lieberman ${ }^{2}$ \\ Catherine Copley- \\ Merriman'}

'RTI Health Solutions, Ann Arbor, MI, 2Mitsubishi Tanabe Pharma America, Inc, Warren, NJ, USA
Correspondence: Vipan Sood Mitsubishi Tanabe Pharma America, Inc, 25 Independence Blvd, Suite 202, Warren, NJ, USA 07059-2732

Tel + I 9086046889

Fax ++19086073000

Email vipan_sood@mt-pharma-us.com
Abstract: Chronic kidney disease (CKD) is a complex debilitating condition affecting more than 70 million people worldwide. With the increased prevalence in risk factors such as diabetes, hypertension, and cardiovascular disease in an aging population, CKD prevalence is also expected to increase. Increased awareness and understanding of the overall CKD burden by health care teams (patients, clinicians, and payers) is warranted so that overall care and treatment management may improve. This review of the burden of CKD summarizes available evidence of the clinical, humanistic, and economic burden of CKD and the current unmet need for new treatments and serves as a resource on the overall burden. Across countries, CKD prevalence varies considerably and is dependent upon patient characteristics. The prevalence of risk factors including diabetes, hypertension, cardiovascular disease, and congestive heart failure is noticeably higher in patients with lower estimated glomerular filtration rates (eGFRs) and results in highly complex CKD patient populations. As CKD severity worsens, there is a subsequent decline in patient health-related quality of life and an increased use of health care resources as well as burgeoning costs. With current treatment, nearly half of patients progress to unfavorable renal and cardiovascular outcomes. Although curative treatment that will arrest kidney deterioration is desired, innovative agents under investigation for CKD to slow kidney deterioration, such as atrasentan, bardoxolone methyl, and spherical carbon adsorbent, may offer patients healthier and more productive lives.

Keywords: quality of life, economics, disease classification, treatment, eGFR

\section{Introduction}

Chronic kidney disease (CKD) is a debilitating disease affecting approximately $7 \%$ of all people aged 30 years and older, which translates to more than 70 million people in developed countries worldwide. ${ }^{1}$ This number is likely to be much higher given the unknown prevalence in underdeveloped countries. The increased prevalence of diabetes, hypertension, and obesity and an aging population will only perpetuate the rise of CKD..$^{2-5}$ Patients have been, and continue to be, diagnosed with CKD later in the disease cycle, and therefore have to be prepared for life on dialysis or to undergo kidney transplant. However, with better screening, early management, and innovative pharmacologic therapies, the disease progression may be delayed and patients with CKD may enjoy healthier and more productive lives.

The objective of this targeted literature review is to present the clinical, humanistic, and economic burden of $\mathrm{CKD}$ and the current corresponding unmet treatment need. We searched the PubMed database via the National Library of Medicine Gateway and conducted supportive desktop research (eg, ClinicalTrials.gov). Search categories 
included "chronic kidney disease," "epidemiology," "disease classification," "progression," "patient-reported outcomes," "economics," and "treatment." The language and date limits applied to the search were English only and 1980 to February 2012, respectively. Original research, key reviews, current guidelines, and drug-specific reports/press releases were selected for inclusion. Findings are presented qualitatively.

The complex clinical nature of CKD is characterized and presented, including a description of the foundational interrelated factors of disease and progression that underlie the true burden and unmet medical needs of CKD. Further, current treatment options are reviewed to outline the existing unmet treatment need. Future treatments under development to address these key unmet needs are also presented.

\section{Increasing prevalence and global burden of CKD}

The trend for increased prevalence of CKD in the USA and select countries, irrespective of the calculation, implies persistent and rapid growth worldwide. Reported prevalence estimates across countries range broadly from approximately $2.0 \%$ to $44 \%{ }^{1-5}$ The broad range in prevalence exemplifies the differences in patient populations and unmet clinical, humanistic, and economic needs across the globe. In the USA, the fastest increase in prevalence is occurring among those aged 65 years and older. Across three databases, the Kidney Early Evaluation Program, National Health and Nutrition Examination Survey, and Medicare, prevalence in the elderly population (aged $\geq 65$ years) was approximately $44 \%$, with the highest representation observed in those aged 80 years and older. ${ }^{4}$ Across countries (Australia, Canada, China, Iceland, Italy, Japan, Mexico, Netherlands, Norway, Singapore, Spain, Switzerland, Thailand, and USA), estimates were similarly high in the elderly and ranged from $23.4 \%$ to $44 \%$. ${ }^{1,4}$

Prevalence estimates for several modifiable risk factors affecting initiation and/or progression of disease have also increased. National Health and Nutrition Examination Survey 2001-2008 data report that diabetes, hypertension, cardiovascular disease, and congestive heart failure are more prevalent in patients with estimated glomerular filtration rates (eGFRs) $<60 \mathrm{~mL} / \mathrm{min} / 1.73 \mathrm{~m}^{2}$; additionally, the prevalence of hypertension is twofold and the prevalence of cardiovascular disease is fivefold greater compared with those with eGFR $>60 \mathrm{~mL} / \mathrm{min} / 1.73 \mathrm{~m}^{2} .^{5}$ As the prevalence of diabetes, hypertension, and other risk factors rise, so does the severity of CKD. For example, the frequency of diabetes increased more than five times by CKD stage and eGFR category.
Diabetes occurred in an estimated $7 \%$ of patients in stage $1 / 2\left(\mathrm{eGFR}>60 \mathrm{~mL} / \mathrm{min} / 1.73 \mathrm{~m}^{2}\right), 18 \%$ of patients in early stage 3 (eGFR $45 \mathrm{~mL} / \mathrm{min} / 1.73 \mathrm{~m}^{2}$ to $<60 \mathrm{~mL} / \mathrm{min} / 1.73 \mathrm{~m}^{2}$ ), $27 \%$ of patients in late stage 3 (eGFR $30 \mathrm{~mL} / \mathrm{min} / 1.73 \mathrm{~m}^{2}$ to $<45 \mathrm{~mL} / \mathrm{min} / 1.73 \mathrm{~m}^{2}$ ), and $40 \%$ of patients in stages 4 and $5\left(\mathrm{eGFR}<30 \mathrm{~mL} / \mathrm{min} / 1.73 \mathrm{~m}^{2}\right){ }^{5}$

Given the increase in CKD prevalence and associated risk factors, more global epidemiological research is needed to better characterize the international burden of CKD. With improved patient-level definitions of CKD, largescale epidemiological studies may present more adequately representative populations with $\mathrm{CKD}$ across countries.

\section{Clinical burden \\ Complexity of disease}

Attention to traditional measures of kidney function (eg, eGFR) is no longer adequate to optimally manage and care for patients with CKD. With the increase in CKD patients diagnosed with diabetes, hypertension, and obesity, consideration must also be given to these and other preexisting, emerging risk factors and comorbid illnesses. Patients with significantly increased risk, with or without confirmed $\mathrm{CKD}$, may require more aggressive management to avoid the consequences of accelerated disease progression.

\section{Disease classification and staging}

The diagnosis, treatment, and management of CKD depend on classification and staging of the disease as set forth by international, country-specific, and other clinical guidelines. ${ }^{6-13}$ As evidenced by a variety of definitions and staging systems in the scientific literature, identification of optimal patient care strategies and interpretation of data are complicated. To date, the most frequently cited and used CKD staging system is that developed by the National Kidney Foundation, Dialysis Outcomes Quality Initiative ${ }^{12,14,15}$ (Table 1).

Although measurement of eGFR is considered the gold standard for diagnosing and evaluating progression of CKD, there is a movement among clinicians and researchers to improve clinical guidelines specifically related to diagnosis, classification, and staging. The following frequently reported criticisms of current guidelines have prompted the discussion for modification of current clinical guidelines. ${ }^{16,17}$

- A diagnosis based on current eGFR estimation formulas is imprecise.

- There is an absence of risk-stratification across patients; those at high risk for disease progression are not identified, and stage 3 is too broad (eg, stage 3 should 
Table I Classification of chronic kidney disease

\begin{tabular}{|c|c|c|c|c|}
\hline \multirow[t]{2}{*}{ Stage } & \multirow[t]{2}{*}{ Description } & \multicolumn{3}{|l|}{ By severity } \\
\hline & & eGFR $\left(\mathrm{mL} / \mathrm{min} / \mathrm{l} .73 \mathrm{~m}^{2}\right)$ & Related terms & By treatment \\
\hline I & $\begin{array}{l}\text { Kidney damage with } \\
\text { normal or } \uparrow \text { eGFR }\end{array}$ & $\geq 90$ & $\begin{array}{l}\text { Albuminuria, proteinuria, } \\
\text { hematuria }\end{array}$ & $\begin{array}{l}\text { "T" for all kidney } \\
\text { transplant recipients }\end{array}$ \\
\hline 2 & $\begin{array}{l}\text { Kidney damage with } \\
\text { mild } \downarrow \text { eGFR }\end{array}$ & $60-89$ & $\begin{array}{l}\text { Albuminuria, proteinuria, } \\
\text { hematuria }\end{array}$ & \\
\hline 3 & Moderate $\downarrow$ eGFR & $30-59$ & $\begin{array}{l}\text { Chronic renal insufficiency, } \\
\text { early renal insufficiency }\end{array}$ & \\
\hline 4 & Severe $\downarrow$ eGFR & $15-29$ & $\begin{array}{l}\text { Chronic renal insufficiency, } \\
\text { late renal insufficiency, } \\
\text { pre-ESRD }\end{array}$ & \\
\hline 5 & Kidney failure & $<15$ (or dialysis) & $\begin{array}{l}\text { Renal failure, uremia, } \\
\text { ESRD }\end{array}$ & $\begin{array}{l}\text { "D" for all dialysis-treated } \\
\text { patients (hemodialysis, } \\
\text { peritoneal dialysis) }\end{array}$ \\
\hline
\end{tabular}

Adapted by permission from Macmillan Publishers Ltd: Kidney Int. ${ }^{100}$ Copyright 2005.

Note: The arrow up indicates increasing eGFR and the arrow down indicates decreasing eGFR.

Abbreviations: ESRD, end-stage renal disease; eGFR, estimated glomerular filtration rate.

be stratified into $3 \mathrm{a}$ [eGFR $45-59 \mathrm{~mL} / \mathrm{min} / 1.73 \mathrm{~m}^{2}$ ] and $3 b$ [eGFR 30-44 mL/min/1.73 $\left.\mathrm{m}^{2}\right]$ ).

- Patient variability (age, sex, race, ethnicity) is not considered in current methods of evaluation (eg, eGFR and proteinuria estimation, at risk for progression, prognosis).

In an effort to collaborate and provide a foundational set of international CKD guidelines that address these criticisms, Kidney Disease Improving Global Outcomes (KDIGO) formed a dedicated workgroup. Publication of the KDIGO "Clinical practice guideline on CKD classification and management" is anticipated in 2012. The proposed guideline structure and associated discussion points are as follows: ${ }^{17}$

- Guideline 1: Definition and stages of CKD. Stages modified and enriched to include different degrees of proteinuria; splitting stage 3 into $3 \mathrm{a}$ and $3 \mathrm{~b}$; define differences between kidney damage and disease.

- Guideline 2: Identification and evaluation of CKD. eGFR, high-risk population evaluation, appropriateness and frequency of testing.

- Guideline 3: Estimation of glomerular filtration rate (GFR). New equations that address "within-individual" biological variability, age, and ethnicity.

- Guideline 4: Estimation of proteinuria. Regional variability in methods; change lexicon from microalbuminuria to albuminuria mild, moderate, or severe.

- Guideline 5: Definition of progression of CKD. Definition of change in eGFR, acute versus chronic change, duration and stability of change, prognostic indicators, frequency of testing.

Because of the complex nature of $\mathrm{CKD}$, emphasis on well-defined disease classification and staging is paramount for optimal patient care. The evidence presented here elucidates several clinical unmet needs: for example, welldefined guidelines for use by primary care physicians, internists, and nephrologists; early identification, prevention, and management of patients at risk for CKD (pre-CKD); "on-time" referral to a nephrologist when patients with early CKD are progressing to intermediate or advanced stages of CKD; optimal management for patients with confirmed $\mathrm{CKD}$ and those at risk for accelerated progression (eg, complex cases with multiple comorbidities); and educational programs and tools developed for primary care physicians, internists, and nephrologists to address a host of topics (eg, clinical guidelines, population-specific treatment, and management).

\section{Risk factors and comorbid illness}

The intertwined nature of risk factors and comorbid illnesses complicates the characterization of CKD. These terms are often used interchangeably due to the continuous and progressive nature of this disease. Some patients may have risk factors for developing CKD, while others may have risk factors contributing to the progression of CKD. Some comorbid illnesses are risk factors for both the initiation and the progression of disease (eg, diabetes and cardiovascular disease). However, some risk factors are simply nonmodifiable patient characteristics (eg, ethnicity, sex). A host of preexisting and traditional progression factors has been reported, with emerging risk factors and biomarkers also identified. ${ }^{18}$ Table 2 presents common risk categories and associated factors.

As noted, some conditions fit across categories (eg, preexisting and advancing cardiovascular disease) and the presence of multiple risk factors and/or comorbid illnesses 
Table 2 Common chronic kidney disease (CKD) risk categories and risk factors

\begin{tabular}{ll}
\hline Risk category & Risk factors \\
\hline Susceptibility & $\begin{array}{l}\text { Older age, reduction in kidney mass, low birth } \\
\text { weight, family history of CKD, US racial or } \\
\text { minority status } \\
\text { Diabetes, hypertension, autoimmune disease, } \\
\text { systemic infections; urinary tract infections, stones, } \\
\text { or obstruction; drug toxicity }\end{array}$ \\
Progression & $\begin{array}{l}\text { Higher proteinuria, hypertension, poor } \\
\text { glycemic control in diabetes, smoking, } \\
\text { obesity, dyslipidemia, cardiovascular } \\
\text { disease, high dietary-protein intake, } \\
\text { decreased nephron number } \\
\text { Lower dialysis dose, temporary vascular }\end{array}$ \\
& $\begin{array}{l}\text { access for hemodialysis, anemia, lower serum } \\
\text { albumin, late referral to nephrologist, mineral } \\
\text { and bone disorders, metabolic acidosis }\end{array}$ \\
\hline
\end{tabular}

Note: Modifiable risk factors are presented in bold.

Adapted with permission from Macmillan Publishers Ltd: Kidney Int. ${ }^{14}$ Copyright 2007. Other sources: Kronenberg ${ }^{18}$; Taal and Brenner ${ }^{99}$; US Renal Data System..$^{61}$

leads to progression of CKD and increased mortality. ${ }^{19}$ Risk factors with overwhelming impacts on patients and health care systems include diabetes, ${ }^{20-25}$ anemia, ${ }^{20,22-31}$ hypertension, ${ }^{20-23,25,27,31}$ and hyperlipidemia. ${ }^{4,20,32-35}$ Patients with multiple risk factors and/or comorbidities bear the greatest burden..$^{22,36,37}$ Importantly, several of the debilitating risk factors and comorbidities are modifiable, and disease progression may be delayed with active patient-clinician collaboration and appropriate treatment. More attention to and early active management of modifiable risk factors and comorbidities are necessary to thwart rapid disease progression.

\section{Disease progression}

Stated simply, in CKD, "disease progression" means deterioration of kidney function. However, the underlying pathophysiology of progression is intricate. It has been postulated that any loss of functional renal mass, irrespective of cause, leads to glomerular hyperfiltration with an increased single-nephron glomerular filtration rate (GFR) and, subsequently, the loss of the ability of the remaining nephrons to autoregulate. ${ }^{14,38,39}$ Renal injury progresses, with glomerular and tubular hypertrophy, sclerosis, and interstitial fibrosis. Proteinuria, decline in GFR, hypertension, kidney failure, and death from uremia are classic clinical features of the renal injury characteristic of progressive CKD. ${ }^{14}$

Few studies with stage-to-stage CKD progression models have been published and each varies in terms of design and population of interest. Common prognostic variables across these models include demographic and laboratory variables such as age, sex, and eGFR, with average kidney function loss, measured by eGFR, between 2 and $8 \mathrm{~mL} / \mathrm{min}$ each year. ${ }^{40-45}$ Tangri and colleagues ${ }^{44}$ found that the addition of fewer standard variables such as diabetes, hypertension status, blood pressure, and body weight demonstrated no improvement in model performance. However, the authors reported that these variables are clearly important for the diagnosis and management of CKD. The high prevalence of these conditions and imprecision with respect to measuring disease severity may have affected performance of these variables in this modeling study. ${ }^{44}$ Further research is needed to accurately predict progression of CKD from those susceptible to and at risk for CKD to those actively progressing through the stages of CKD. Of note, two ongoing studies, the Chronic Renal Insufficiency Cohort study ${ }^{46}$ and the CKD Prognosis Consortium meta-analyses, ${ }^{16}$ are actively engaged in research to better understand kidney function and risk factors of CKD progression in diverse and complex patient populations.

\section{Humanistic burden}

Patient perspective is an important component of CKDrelated care. In the case of any chronic disease without a cure, patient perspective can be the best source for understanding the illness experience, treatment expectations and experience, and unmet needs with current treatments. Given the few studies identified with measures of CKD burden from the patient's perspective, opportunities for this type of research are vast.

The most burdensome conditions commonly reported by CKD patients across identified studies were cognitive impairment, dementia, sleep disturbance, pain, and emotional and physical dysfunction. Of these, physical dysfunction was the most pervasive and debilitating. ${ }^{47-54}$ Instruments used to measure patient perspective were the Medical Outcomes Study Short Form - 36, the Kidney Disease Quality of Life Short Form - 36 (KDQOL-36), Health Utilities Index 3, and a time trade-off approach. ${ }^{47,48,50,53,54}$ Perception of general health as measured by the Medical Outcomes Study Short Form - 36 was low across all eGFR groups defined by Chin and colleagues. ${ }^{47}$ With an increase in illness severity and a decrease in eGFR, mental health component scores were similarly low across groups, whereas the physical component scores were reduced significantly with reduced eGFR, particularly in those with an eGFR $<45 \mathrm{~mL} / \mathrm{min} / 1.73 \mathrm{~m}^{2}$ (stage 3) and $30 \mathrm{~mL} / \mathrm{min} / 1.73 \mathrm{~m}^{2}$ (stage 4). ${ }^{47,53}$ When compared with the general population, patients with CKD scored lower on six of 
eight subscales - physical function, role limitation - physical, general health, vitality, role limitation - emotional, and the physical component score. ${ }^{50}$ Mean scores on KDQOL-36 components, Health Utilities Index 3, and time trade-off suggested considerable loss of function and well-being in patients with CKD compared with the general population. Decline in eGFR was also monotonically associated with a decline in patient-reported health as measured by the Burden of Kidney Disease (BKD) and the Effects of Kidney Disease subscales (EKD) of the KDQOL-36 (CKD-specific measures; higher score indicates better health). The scores were highest (BKD: 85.9; EKD: 92.4) in patients with eGFR $>60 \mathrm{~mL} / \mathrm{min} / 1.73 \mathrm{~m}^{2}$ (stage 1-2). With subsequent decreases in eGFR, perceived health decreased. For those with stage 3 CKD $\left(30 \mathrm{~mL} / \mathrm{min} / 1.73 \mathrm{~m}^{2} \leq \mathrm{eGFR}<60 \mathrm{~mL} / \mathrm{min} / 1.73 \mathrm{~m}^{2}\right)$, BKD was 85.4 and EKD was 91.6, with continued reduction to a BKD of 74.9 and EKD of 87.5 for those with stage 4 $\left(15 \mathrm{~mL} / \mathrm{min} / 1.73 \mathrm{~m}^{2} \leq \mathrm{eGFR}<30 \mathrm{~mL} / \mathrm{min} / 1.73 \mathrm{~m}^{2}\right)$, and BKD of 63.4 and EKD of 80.4 for those with stage 5 (eGFR $<15 \mathrm{~mL} / \mathrm{min} / 1.73 \mathrm{~m}^{2}$ ). The lowest perceived health (BKD: 38.6; EKD: 62.7) was observed in patients on dialysis. ${ }^{48}$ Modifiable risk factors associated with lower quality of life were less education, less exercise, depression, history of cardiovascular disease, lower income, and unemployment. ${ }^{47,48,53}$
Figures 1 and 2 highlight the decline in health-related quality of life with the progression of CKD.

\section{Economic burden}

$\mathrm{CKD}$ is associated with significant economic burden. Disease progression, increased disease severity, and deterioration of health increase resource utilization and escalate costs. Across identified studies, in the 12 to 24 months before dialysis initiation, substantial increases in costs due to hospitalization were reported..$^{20,21,23,25,32,36,55-58}$ A study in a Medicare-claims cohort of patients with CKD reported the annual mean number of days hospitalized (9.51) and mean number of physician visits (10.28). ${ }^{59}$ The mean annual number of physician visits increased monotonically by CKD stage, with 4.43 visits in early stage CKD (stages 1 and 2 combined) and 6.53 visits in late-stage CKD (stages 3 and 4 combined). ${ }^{55}$ Available cost data worldwide were from the USA and Germany. Irrespective of country and cost measure used (eg, total health care costs per patient, in-hospital costs, total medical payments) in each study, the identified costs were consistently high and increased with each CKD stage. Across CKD stages, total health care costs per patient ranged from US\$1183 to $\$ 35,292$ (per month) in the USA; annual and in-hospital costs were $€ 3581$ and $€ 2926$ to $€ 9687$,

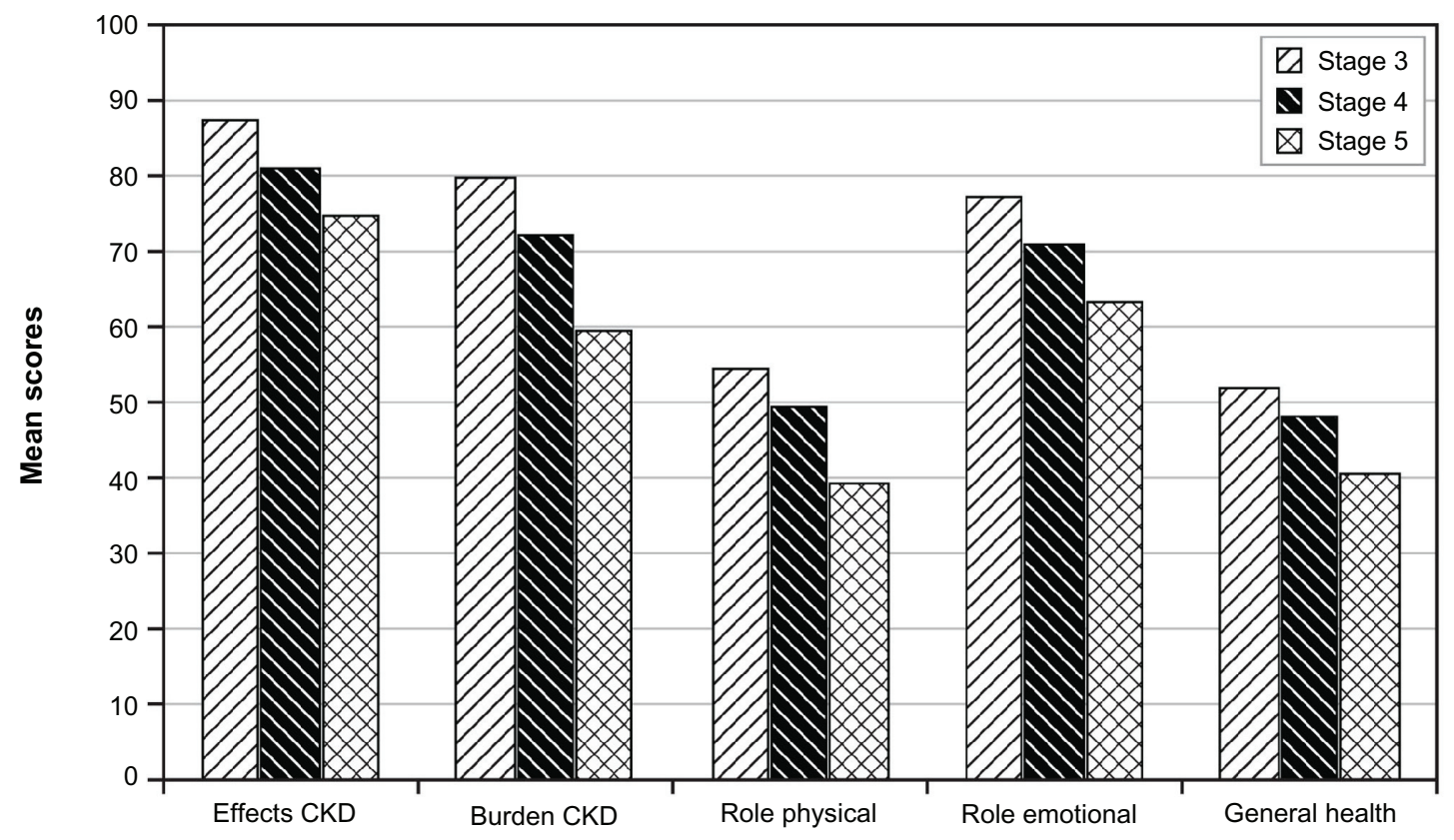

KDQOL-36 domains

Figure I Health-related quality of life and progression of chronic kidney disease (CKD) by stage.

Note: Statistical significance observed for trend within each domain $P<0.00$ I.

Adapted from Clin J Am Soc Nephrol. Mujais SK, Story K, Brouillette J, et al. Health-related quality of life in CKD patients: correlates and evolution over time. Copyright. 2009. ${ }^{51}$

Abbreviation: KDQOL-36, Kidney Disease Quality of Life - 36. 


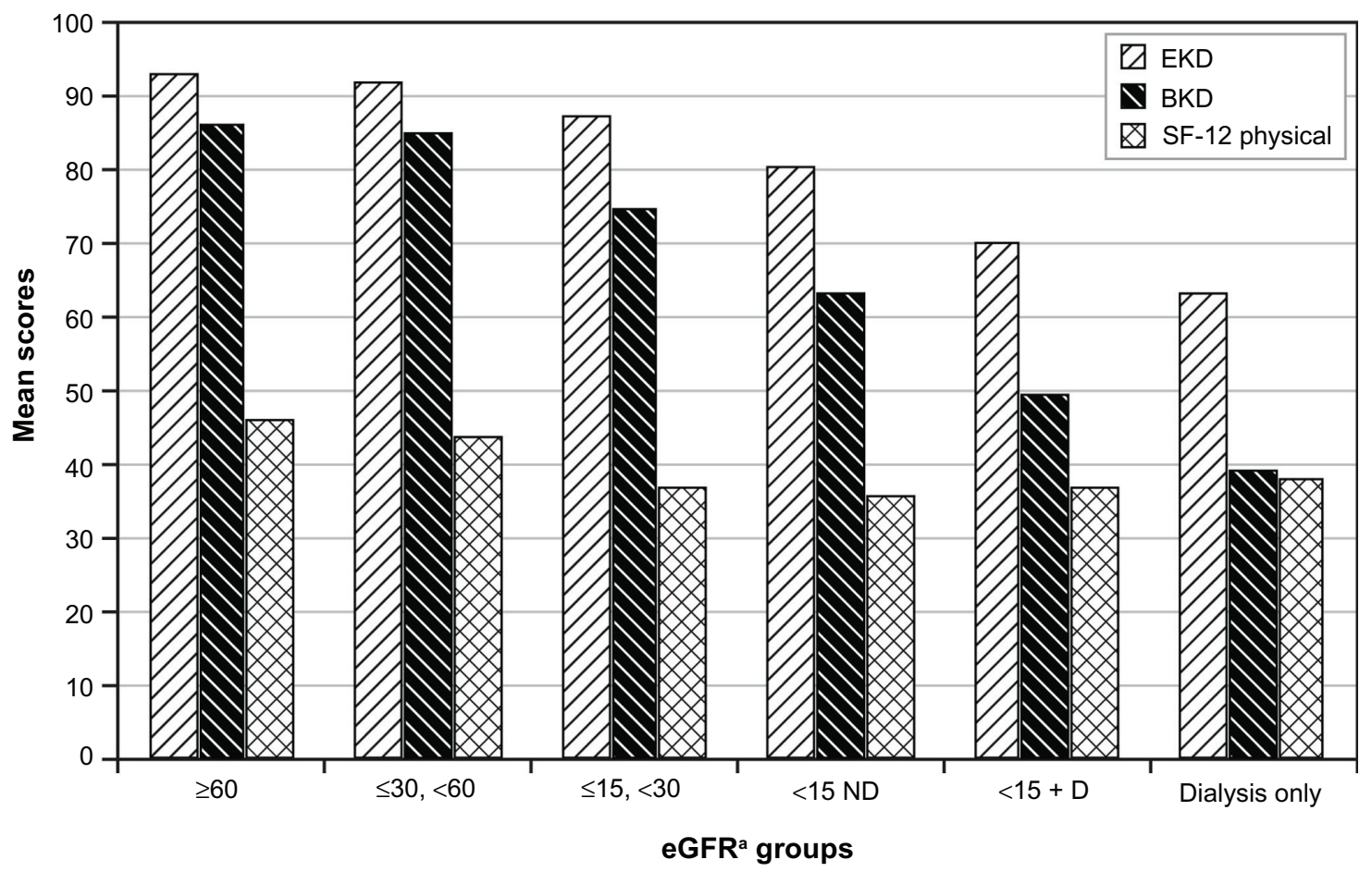

Figure 2 Health-related quality of life (HRQOL), quality of life (QOL), and progression of chronic kidney disease by glomerular filtration rate.

Notes: ${ }^{a} \mathrm{~mL} / \mathrm{min} / 1.73 \mathrm{~m}^{2}$. HRQOL measured by Kidney Disease Quality of Life (KDQOL) - 36; QOL measured by SF-I2; EKD: $P<0.000 \mathrm{I}$ for all nondialysis and dialysis only groups; BKD: $P=0.0002$ for all nondialysis groups; $P<0.000$ I for dialysis only group; $S F-12$ Physical: $P=0.000$ I for all nondialysis groups; $P=0.0002$ for dialysis only group. Adapted with permission from Macmillan Publishers Ltd: Kidney Int. ${ }^{48}$ Copyright 2005.

Abbreviations: BKD, Burden of Kidney Disease, subscale of Kidney Disease Quality of Life; D, dialysis; CKD, chronic kidney disease; EKD, Effects of Kidney Disease; subscale of eGFR, estimated glomerular filtration; KDQOL; SF-I2 Physical, Medical Outcomes Study Short Form - I2, physical component; ND, no dialysis.

respectively, in Germany. ${ }^{20,25,33,60,61}$ By stage, cost data were available from select studies (Table 3).

In reported studies, the impact of CKD on employers is also significant. Of the studies identified, most were conducted in an older working population with CKD. This was not unexpected given that most patients with CKD are elderly. As the general working population increasingly includes individuals older than 65 years, the working population with CKD may also increase, thereby placing a profound and growing burden on employers.

All identified studies that evaluated an employer population with CKD were conducted in the USA. ${ }^{29,37,62,63}$ In a matched case-control study, employees with CKD were older; more likely to be male; and more likely to have hypertension, diabetes, and other chronic comorbid conditions than controls. ${ }^{37}$ Annual costs attributable to CKD

Table 3 Increased cost by chronic kidney disease (CKD) stage

\begin{tabular}{|c|c|c|c|c|c|}
\hline $\begin{array}{l}\text { Country, cost measure } \\
\text { (denomination) }\end{array}$ & Stage I & Stage 2 & Stage 3 & Stage 4 & Stage 5 \\
\hline \multicolumn{6}{|l|}{ USA } \\
\hline $\begin{array}{l}\text { Employer, unadjusted total medical } \\
\text { payments (US\$) }\end{array}$ & - & - & $\$ 9727$ & $\$ 19,419$ & $\$ 30,366$ \\
\hline $\begin{array}{l}\text { Employer, per member per year costs } \\
(\text { US\$) })^{62}\end{array}$ & $\$ 5000-\$ 12,000$ & & $\$ 15,000-\$ 28,000$ & & Exceeds $\$ 70,000$ \\
\hline $\begin{array}{l}\text { Managed care, annualized total medical } \\
\text { costs (US\$) }\end{array}$ & - & $\$ 7050$ & $\$ 6026$ & $\$ 7623$ & - \\
\hline $\begin{array}{l}\text { Managed care, annual total health care } \\
\text { costs of CKD in specialist clinic and } \\
\text { other setting (US\$) })^{58}\end{array}$ & - & - & $\$ 10,132-\$ 14,000$ & $\$ 12,386-\$ 16,545$ & $\$ 18,522-\$ 23,445$ \\
\hline \multicolumn{6}{|l|}{ Germany } \\
\hline Hospital data, in-hospital costs $(€)^{33}$ & $€ 2926$ & $€ 3466$ & $€ 4208$ & $€ 9687$ & \\
\hline
\end{tabular}


ranged from US\$1187 for stage 3 to US $\$ 21,826$ for stage $5 .{ }^{37}$ Upon evaluation of an employer-sponsor population health improvement program, workdays missed exceeded 10 hours per week for employees with CKD. ${ }^{64}$ Unadjusted costs are presented in Table 3.

Anemia-related morbidity is of significant concern in the workplace. Overall burden and/or costs for patients with CKD and anemia are significantly higher than for those with CKD and no anemia. ${ }^{24,26}$ Treatment for predialysis employees with anemia resulted in improved work productivity by $91.5 \%$, reduced absenteeism by 52.3 days per year, and reduced health care costs by approximately US $\$ 4417$ per patient per year. ${ }^{63}$ A similar study reported incremental direct and indirect cost savings with anemia treatment in employees with CKD and anemia compared with those whose anemia was untreated. ${ }^{29}$

\section{Current treatment options}

Over the past few decades, few new treatment options have been made available for CKD patients. Without curative treatment, the primary aims remain to slow the progression of CKD and subsequent loss of kidney function and cardiovascular disease. Current objectives to address these outcomes include control of hypertension, dyslipidemia, proteinuria, hyperglycemia, anemia, and bone mineral disorders. ${ }^{12}$ Given the complex nature of CKD and the interrelated risk factors, comorbidities, and complications represented in these patients, a comprehensive and collaborative treatment strategy of nonpharmacological (lifestyle management) and pharmacological management is recommended.

\section{Lifestyle management}

Key components of lifestyle management are those supporting the primary treatment aims of CKD. Obesity, smoking, sedentary lifestyle, high cholesterol, and hypertension increase the risk for adverse outcomes in patients with CKD. ${ }^{12,42,65-70}$ Other important components of lifestyle management are mental health and social support. Although understudied, an important pilot study in late CKD was identified. Cabness et $\mathrm{al}^{71}$ proposed evaluation of psychological measures linked to biophysiological measures in patients with CKD. As has been found with other chronic and debilitating diseases, mental health and social support may be of significant value to patients with $\mathrm{CKD} .^{72}$

\section{Current renoprotective drug therapy}

Current renoprotective drug therapy includes treatment with angiotensin-converting enzyme inhibitors (ACEIs), angiotensin-receptor blockers (ARBs), statins, insulins, and insulin sensitizers, depending on patient need. All of these therapies reduce proteinuria. In addition to their primary use, antihypertensive agents and those for hyperglycemia also demonstrate a slowed decline in or improvement of GFR. Supporting studies for each class are summarized in current Kidney Disease Outcomes Quality Initiative guidelines. $^{73}$

\section{Hypertension}

Optimum control of hypertension is paramount in the management of CKD. In multiple clinical trials, ACEIs or ARBs slowed progression of diabetic and nondiabetic kidney disease between $16 \%$ and 56\%. ${ }^{74-79}$ The landmark trial by the Collaborative Study Group demonstrated the effectiveness of ACEIs in slowing progression of diabetes and $\mathrm{CKD}$ in patients with type 1 diabetes and macroalbuminuria, regardless of presence or absence of hypertension. ${ }^{77}$ In patients with type 2 diabetes and overt nephropathy, ARBs were more effective than conventional therapy in the progression of nephropathy, despite similar blood pressure control. ${ }^{74,77,80}$ In patients with nondiabetic CKD, ACEIs slowed disease progression, and the benefits were greater in patients with higher levels of proteinuria. ${ }^{75,78,79,81}$ As evidenced by the African American Study of Kidney Disease trial, setting blood pressure targets reduced proteinuria and slowed progression in African Americans with hypertensive CKD ${ }^{82}$ Special attention and further research are needed to optimally manage hypertension in other at-risk and highrisk populations.

\section{Dyslipidemia}

Dyslipidemia is a cardiovascular risk factor for CKD. It is associated with decreased renal function in the general population and in patients with CKD. Statins (3-hydroxy-3methyl-glutaryl-CoA reductase inhibitors) are recommended for treatment of dyslipidemia in patients with CKD. ${ }^{73}$ Results from the landmark Study of the Heart and Renal Protection (SHARP) trial support statin therapy to reduce cardiovascular events in a varied group of patients with advancing CKD. Although improvement in renal outcomes was not found, a $17 \%$ risk reduction in major atherosclerotic events was observed in CKD patients treated with ezetimibe and simvastatin compared with placebo, despite lower compliance (ezetimibe/simvastatin: 71\%; placebo: $9 \%$ ). ${ }^{83}$ With improved compliance, statin therapy may result in significantly greater cardiovascular benefits than observed in Study of Heart and Renal Protection (SHARP). ${ }^{83}$ 


\section{Hyperglycemic control for diabetic nephropathy}

Hyperglycemia, the defining feature of diabetes, is a fundamental cause of kidney damage. In patients with diabetes, the target $\mathrm{HbA}_{1 \mathrm{c}}$ (glycated hemoglobin) is less than $7 \%$. Intensive glycemic control prevents the development and progression of albuminuria. ${ }^{84-87}$ The Diabetes Control and Complications Trial (DCCT) demonstrated a $54 \%$ reduction in risk of albuminuria in patients with type 1 diabetes with intensive antihyperglycemic therapy. ${ }^{84}$ The follow-up study to DCCT, Epidemiology of Diabetes Interventions and Complications (EDIC), demonstrated persistent beneficial effects on albumin excretion and reduced incidence of hypertension up to 8 years after the DCCT study was completed. Long-term benefits of intensive treatment were clearly demonstrated in the EDIC study. ${ }^{85}$ No data evaluating the renoprotective effects of tight glycemic control in patients with established nephropathy were identified.

Although current renoprotective pharmacotherapies are the mainstay of CKD treatment, they are only partially effective; $20 \%$ to $40 \%$ of patients progress to unfavorable renal outcomes in spite of therapy. ${ }^{88}$ None of the current agents target all pathological mechanisms in CKD. Nor do they adequately reduce eGFR decline or significantly delay or stop progression to ultimately reverse disease or thwart adverse renal endpoints. Therefore, continued research to find new agents with new mechanisms of action may lead to more effective therapy for patients with CKD (Table 4).

\section{Emerging renoprotective drug therapy}

A variety of new renoprotective agents targeting primary destructive pathological mechanisms of CKD are in

Table 4 Current renoprotective drug therapy

\begin{tabular}{ll}
\hline $\begin{array}{l}\text { Risk factor or comorbid condition } \\
\text { and current therapy }\end{array}$ & $\begin{array}{l}\text { Renoprotective } \\
\text { effects }\end{array}$ \\
\hline $\begin{array}{l}\text { Hypertension } \\
\text { Angiotensin-converting enzyme inhibitors }\end{array}$ & $\begin{array}{l}\text { Lower blood pressure } \\
\text { Reduce proteinuria } \\
\text { Slow decline or }\end{array}$ \\
Angiotensin-receptor blockers & improved GFR \\
Dyslipidemia & $\begin{array}{l}\text { Lower cholesterol } \\
\text { Reduce proteinuria }\end{array}$ \\
Hyperglycemia & $\begin{array}{l}\text { Reduce proteinuria } \\
\text { Insulin }\end{array}$ \\
Insulin sensitizers & $\begin{array}{l}\text { Slow decline or } \\
\text { improve GFR }\end{array}$ \\
\hline
\end{tabular}

Note: Hirsch ${ }^{88}$ and National Kidney Foundation. ${ }^{12}$

Abbreviation: GFR, glomerular filtration rate. development. ${ }^{89}$ Those identified via ClinicalTrials.gov include AST-120 (spherical carbon adsorbent), atrasentan, bardoxolone methyl, CTP-499, pentoxifylline, and VTP-27999. To date, AST-120 and bardoxolone methyl have advanced to Phase III clinical trials. ${ }^{90-92}$ Brief descriptions of agents with ongoing Phase II and Phase III trials follow.

\section{Atrasentan (ABT-627)}

Atrasentan is a highly selective endothelin-A receptor antagonist that blocks the effect of endothelin-1, a protein that constricts blood vessels, raises blood pressure, and affects kidney function. Phase II data with atrasentan showed reduction in albuminuria. ${ }^{90}$ A Phase IIb study is recruiting patients with type 2 diabetes and nephropathy currently treated with the maximum tolerated dose of a renin-angiotensin system inhibitor. Atrasentan (dose not reported) is an oral agent with once-daily administration. ${ }^{93}$ Data availability was not reported.

\section{Bardoxolone methyl (RTA-402)}

Bardoxolone methyl is an antioxidant inflammation modulator - a potent inducer of the transcription factor $\mathrm{NrF} 2$, an important biological target that controls the production of many of the body's detoxification enzymes. This agent activates the $\mathrm{NrF} 2$ pathway aiming to decrease oxidative stress and inflammation, which contributes to kidney decline. Phase IIb data suggest the potential to prevent patients from progressing to later-stage disease and dialysis; reversal of disease is also suggested. A Phase III clinical trial, Bardoxolone Methyl Evaluation in Patients with Chronic Kidney Disease and Type 2 Diabetes is currently recruiting patients with CKD in type 2 diabetes. Bardoxolone methyl $20 \mathrm{mg}$ is an oral agent with once-daily administration. Trial results are expected in June 2013.90,91

Table 5 Key emergent renoprotective drug therapy

\begin{tabular}{|c|c|c|}
\hline Drug/Phase & $\begin{array}{l}\text { Mechanism } \\
\text { of action }\end{array}$ & Sponsor \\
\hline $\begin{array}{l}\text { Bardoxolone methyl } \\
\text { (RTA-402) Phase III }\end{array}$ & $\begin{array}{l}\text { Activation and modulation } \\
\text { of Nrf2 (anti-inflammatory } \\
\text { effect) }\end{array}$ & $\begin{array}{l}\text { Reata } \\
\text { pharmaceuticals }\end{array}$ \\
\hline $\begin{array}{l}\text { Spherical carbon adsorbent } \\
\text { (AST-I20) Phase IIII2,95 }\end{array}$ & $\begin{array}{l}\text { Spherical carbon } \\
\text { adsorbent of uremic } \\
\text { toxins }\end{array}$ & $\begin{array}{l}\text { Mitsubishi } \\
\text { Tanabe Pharma } \\
\text { and Kureha }\end{array}$ \\
\hline $\begin{array}{l}\text { Atrasentan } \\
\text { (ABT-627) Phase } 1 \text { llb }^{93}\end{array}$ & $\begin{array}{l}\text { Blocks effect of } \\
\text { endothelin-1 }\end{array}$ & Abbott \\
\hline CTP-499 Phase ${ }^{96}$ & $\begin{array}{l}\text { Anti-inflammatory, } \\
\text { antioxidant, } \\
\text { antifibrotic }\end{array}$ & $\begin{array}{l}\text { Concert } \\
\text { pharmaceuticals }\end{array}$ \\
\hline VTP-27999 Phase I77 & $\begin{array}{l}\text { Selective renin } \\
\text { inhibitor }\end{array}$ & $\begin{array}{l}\text { Vitae } \\
\text { pharmaceuticals }\end{array}$ \\
\hline
\end{tabular}




\section{Spherical carbon adsorbent (AST-I20)}

AST-120 is a spherical carbon adsorbent that acts locally to remove uremic toxins and precursors in the gastrointestinal tract, thereby preventing saturation in the blood stream and nephrotoxicity. It has been approved and marketed in Japan, South Korea, and the Philippines for prolonging time to initiation of dialysis therapy and improving uremic symptoms in patients with chronic renal failure. ${ }^{94}$ Two Phase III outcome clinical trials have been completed and data are forthcoming: ${ }^{92,95}$ Evaluating Prevention of Progression in Chronic Kidney Disease and Evaluating Prevention of Progression in Chronic Kidney Disease Including Assessment of Quality of Life. The trials evaluated AST-120 added to standard-of-care therapy for prevention of progression in moderate to severe CKD. The dosage studied in clinical trials was $9 \mathrm{~g} /$ day, divided into three doses per day. Clinical endpoints studied include initiation of dialysis, kidney transplant, or doubling of serum creatinine.

\section{Other agents}

Other promising agents planned for entry into Phase II trials include CTP-499, a first-in-class candidate from the deuterium platform, with anti-inflammatory, anti-fibrotic, and antioxidant properties, ${ }^{96}$ and VTP-27999, a potent selective renin inhibitor; ${ }^{97}$ Phase II studies are not yet recruiting. Aliskiren was a promising agent for high-risk patients with diabetes and renal impairment until an interim review by the data-monitoring committee concluded that patients were unlikely to benefit from treatment added on top of standard antihypertensives. In addition, treatment with aliskiren was associated with more adverse events than other treatments. Upon recommendation by the data-monitoring committee, the trial was terminated in December 2011.98

Emergent drug therapies with anticipated renoprotective effects are presented in Table 5. These agents provide new therapeutic options for patients with CKD. Several agents have new or unique mechanisms of action and better outcomes may be expected. For agents that have advanced to Phase III trials, positive efficacy and safety outcomes are anticipated.

\section{Conclusion}

The overarching, primary unmet need for new treatment for CKD is evident. Curative treatment or the ability to arrest deterioration of the kidney in CKD is not currently possible. However, several related unmet needs provide opportunity for action. This review has summarized the considerable clinical, humanistic, and economic CKD burden; resulting unmet need; and promising new pharmacological agents that target multiple pathological mechanisms or mechanisms marginally affected by traditional therapies.

Because CKD is prevalent and growing globally, the paucity of studies across disciplines on this topic is a cause for concern. In currently available research, broad study populations characteristic of patients with CKD are not adequately represented, nor are countries. Prospective epidemiological studies are needed to adequately characterize patient populations, particularly in countries with the most rapid increase in CKD rates. This research would support disease classification and staging efforts.

Patients are key decision makers in the health care process. Qualitative research with a focus on the patient perspective has been scant. Patients can be the best source for researchers and clinicians to understand the patient's illness experience, level of health literacy, treatment expectations and experience, and unmet needs with current treatments. Placing more emphasis on the patient perspective could improve and benefit overall care.

Although the majority of papers identified were in the field of health economics, more research is needed to better understand costs (direct and indirect) in different patient populations (eg, different ethnic groups, patients of working age, and patients with multiple comorbidities), in different settings (eg, employer, managed care, Medicare, Medicaid, and national plans) across countries.

As reported, several sponsor agencies worldwide have developed guidelines for the treatment of CKD. In 2012, KDIGO is expected to publish new international guidelines on this topic. Anticipated improved classification and staging may support earlier recognition of kidney dysfunction in the primary care setting, better referral to nephrologists, and targeted treatment plans by stage of CKD.

Continued basic and clinical trial research is needed to improve the understanding of pathological mechanisms associated with CKD initiation and progression, as well as the effects of treatment in various patient populations worldwide. Better understanding of the mechanisms may lead to the development of drugs that will stop the deterioration of the kidneys, reverse disease, or effect a cure.

CKD is a prevalent, complex, and growing condition worldwide. With the aging of the population and the increase of risk factors associated with initiation and progression of disease in many nations, a significant burden is placed on patients, families, employers, health care systems, and society as a whole. With action, the unmet needs identified in this 
review can be addressed. The ultimate goal is to discover a curative treatment or one that will arrest deterioration of the kidney. This will offer patients healthier and more productive lives and, eventually, decrease overall system costs so that scarce resources can be allocated elsewhere.

\section{Acknowledgments}

We would like to thank Bonnie Kase for her scientific review and Kate Lothman for her high-quality editorial contributions.

\section{Authors' contributions}

LB and SH performed the review and wrote the first draft. VS and BL reviewed all drafts. CCM and LB wrote the final draft. All authors contributed to the conception and design, and read and approved the final manuscript.

\section{Disclosure}

Mitsubishi Tanabe Pharma Corporation provided financial support for this research. VS and BL are employees of Mitsubishi Tanabe Pharma America. LB, SH, and CCM have acted as research consultants to Mitsubishi Tanabe Pharma America. The authors declare no other competing interests with respect to this article.

\section{References}

1. Zhang QL, Rothenbacher D. Prevalence of chronic kidney disease in population-based studies: systematic review. BMC Public Health. 2008;8:117.

2. Collins AJ. Figure 12.1. In: CKD and the Public Health Agenda for Chronic Diseases. Vol 2. Available from: http://www.worldkidneyday. org/page/prevalence-of-disease. Accessed February 17, 2012.

3. Coresh J, Selvin E, Stevens LA, et al. Prevalence of chronic kidney disease in the United States. JAMA. 2007;298(17):2038-2047.

4. Stevens LA, Li S, Wang C, et al. Prevalence of CKD and comorbid illness in elderly patients in the United States: results from the Kidney Early Evaluation Program (KEEP). Am J Kidney Dis. 2010;55(3 Suppl 2): S23-S33.

5. US Renal Data System (USRDS). Costs of CKD. In: 2011 USRDS Annual Data Report. Volume One: Atlas of Chronic Kidney Disease in the United States. Bethesda, MD: National Institutes of Health, National Institute of Diabetes and Digestive and Kidney Diseases; 2011. Available from: http://www.usrds.org/2011/pdf/v1_ch06_11.pdf. Accessed February 17, 2012.

6. Nephrology Pharmacy Associates, Inc; In: Bailie GR, Johnson CA, Mason NA, St Peter WL, editors. Chronic Kidney Disease 2006: A Guide to Select NKF-KDOQI Guidelines and Recommendations. New York, NY: National Kidney Foundation. Available from: http://www.kidney.org/ professionals/kls/pdf/Pharmacist_CPG.pdf. Accessed February 17, 2012.

7. Kidney Disease Outcomes Quality Initiative (KDOQI). KDOQI Clinical Practice Guidelines and Clinical Practice Recommendations for Diabetes and Chronic Kidney Disease. Am J Kidney Dis. 2007;49(2 Suppl 2):S12-S154.

8. Levin A, Hemmelgarn B, Culleton B, et al; Canadian Society of Nephrology. Guidelines for the management of chronic kidney disease. CMAJ. 2008;179(11):1154-1162.

9. MacGregor MS, Taal MW. Renal Association Clinical Practice Guideline on detection, monitoring and management of patients with CKD. Nephron Clin Pract. 2011;118 Suppl 1:c71-c100.
10. National Collaborating Centre for Chronic Conditions. Chronic kidney disease: early identification and management of chronic kidney disease in adults in primary and secondary care. Clinical guideline no 73 [updated Sep 2008; cited February 17, 2012]. Available from: http://www.guideline. gov/content.aspx?id=14330. Accessed February 17, 2012.

11. National Institute for Health and Clinical Excellence. Early identification and management of chronic kidney disease in adults in primary and secondary care. Clinical guideline no. 73 [updated March 30, 2010; cited February 17, 2012]. Available from: http://guidance.nice.org.uk/ CG73/Guidance/pdf/English. Accessed February 17, 2012.

12. National Kidney Foundation. K/DOQI clinical practice guidelines for chronic kidney disease: evaluation, classification, and stratification. Am J Kidney Dis. 2002;39(2 Suppl 1):S1-S266.

13. Scottish Intercollegiate Guidelines Network (SIGN). Diagnosis and management of chronic kidney disease: a national guideline [updated 2008; cited February 17, 2012]. Available from: http:/www.sign.ac.uk/ pdf/sign103.pdf. Accessed February 17, 2012.

14. Levey AS, Atkins R, Coresh J, et al. Chronic kidney disease as a global public health problem: approaches and initiatives - a position statement from Kidney Disease Improving Global Outcomes. Kidney Int. 2007;72(3):247-259.

15. Hallan SI, Orth SR. The conundrum of chronic kidney disease classification and end-stage renal risk prediction in the elderly - what is the right approach? Nephron Clin Pract. 2010;116(4): c307-c316.

16. Levey AS, de Jong PE, Coresh J, et al. The definition, classification, and prognosis of chronic kidney disease: a KDIGO Controversies Conference report. Kidney Int. 2011;80(1):17-28.

17. Kidney Disease Improving Global Outcomes (KDIGO). Guideline scope. In KDIGO guideline for CKD classification and management [web page on the Internet]. Available from: http://www.kdigo. org/clinical_practice_guidelines/CKD.php. Accessed February 17, 2012.

18. Kronenberg F. Emerging risk factors and markers of chronic kidney disease progression. Nat Rev Nephrol. 2009;5(12):677-689.

19. Keith DS, Nichols GA, Gullion CM, Brown JB, Smith DH. Longitudinal follow-up and outcomes among a population with chronic kidney disease in a large managed care organization. Arch Intern Med. 2004;164(6):659-663.

20. Baumeister SE, Böger CA, Krämer BK, et al. Effect of chronic kidney disease and comorbid conditions on health care costs: A 10-year observational study in a general population. Am J Nephrol. 2010;31(3):222-229.

21. Kubacki M, Carter C, Herrera AD, Wang J, Lopez JM, Piech CT. Health plan retention and pharmacy costs of newly diagnosed patients with chronic kidney disease in a managed care population. American Health and Drug Benefits. 2009;2(7):283-290.

22. Laliberté F, Bookhart BK, Vekeman F, et al. Direct all-cause health care costs associated with chronic kidney disease in patients with diabetes and hypertension: a managed care perspective. J Manag Care Pharm. 2009; 15(4):312-322.

23. London R, Solis A, Goldberg GA, Wade S, Chan WW. Examination of resource use and clinical interventions associated with chronic kidney disease in a managed care population. J Manag Care Pharm. 2003;9(3):248-255.

24. Nissenson AR, Collins AJ, Hurley J, Petersen H, Pereira BJ, Steinberg EP. Opportunities for improving the care of patients with chronic renal insufficiency: current practice patterns. J Am Soc Nephrol. 2001;12(8):1713-1720.

25. Robbins JD, Kim JJ, Zdon G, Chan WW, Jones J. Resource use and patient care associated with chronic kidney disease in a managed care setting. J Manag Care Pharm. 2003;9(3):238-247.

26. Ershler WB, Chen K, Reyes EB, Dubois R. Economic burden of patients with anemia in selected diseases. Value Health. 2005;8(6): 629-638.

27. Khan S, Amedia CA Jr. Economic burden of chronic kidney disease. J Eval Clin Pract. 2008;14(3):422-434. 
28. Lefebvre P, Duh MS, Buteau S, Bookhart B, Mody SH. Medical costs of untreated anemia in elderly patients with predialysis chronic kidney disease. J Am Soc Nephrol. 2006;17(12):3497-3502.

29. Moyneur E, Bookhart BK, Mody SH, Fournier AA, Mallett D, Duh MS. The economic impact of pre-dialysis epoetin alpha on health care and work loss costs in chronic kidney disease: an employer's perspective. Dis Manag. 2008;11(1):49-58.

30. van Nooten FE, Green J, Brown R, Finkelstein FO, Wish J. Burden of illness for patients with non-dialysis chronic kidney disease and anemia in the United States: review of the literature. $J$ Med Econ. 2010;13(2):241-256

31. Wish J, Schulman K, Law A, Nassar G. Healthcare expenditure and resource utilization in patients with anaemia and chronic kidney disease: a retrospective claims database analysis. Kidney Blood Press Res. 2009;32(2):110-118.

32. Khan SS, Kazmi WH, Abichandani R, Tighiouart H, Pereira BJ, Kausz AT. Health care utilization among patients with chronic kidney disease. Kidney Int. 2002;62(1):229-236.

33. Meyer A, Bunzemeier H, Hausberg M, et al. Impact of different stages of chronic kidney disease on in-hospital costs in patients with coronary heart disease. Nephrol Dial Transplant. 2008;23(6): 1955-1960.

34. Schumock GT, Andress DL, Marx SE, Sterz R, Joyce AT, KalantarZadeh K. Association of secondary hyperparathyroidism with CKD progression, health care costs and survival in diabetic predialysis CKD patients. Nephron Clin Pract. 2009;113(1):c54-c61.

35. Thorp ML, Eastman L, Smith DH, Johnson ES. Managing the burden of chronic kidney disease. Dis Manag. 2006;9(2):115-121.

36. Smith DH, Gullion CM, Nichols G, Keith DS, Brown JB. Cost of medical care for chronic kidney disease and comorbidity among enrollees in a large HMO population. J Am Soc Nephrol. 2004;15(5): 1300-1306.

37. Taylor TN, Salinitri FD, Satterhwaite DW. Medical care spending associated with chronic kidney disease by stage of disease [abstract PUK9]. Value Health. 2011;14(3):A75.

38. Brenner BM, Goldszer RC, Hostetter TH. Glomerular response to renal injury. Contrib Nephrol. 1982;33:48-66.

39. Hostetter TH, Olson JL, Rennke HG, Venkatachalam MA, Brenner BM. Hyperfiltration in remnant nephrons: a potentially adverse response to renal ablation. Am J Physiol. 1981;241(1):F85-F93.

40. Barbour SJ, Er L, Djurdjev O, Karim M, Levin A. Differences in progression of CKD and mortality amongst Caucasian, Oriental Asian and South Asian CKD patients. Nephrol Dial Transplant. 2010;25(11): 3663-3672.

41. Djamali A, Kendziorski C, Brazy PC, Becker BN. Disease progression and outcomes in chronic kidney disease and renal transplantation. Kidney Int. 2003;64(5):1800-1807.

42. Kukla A, Adulla M, Pascual J, et al. CKD stage-to-stage progression in native and transplant kidney disease. Nephrol Dial Transplant. 2008;23(2):693-700

43. Orlando LA, Belasco EJ, Patel UD, Matchar DB. The chronic kidney disease model: a general purpose model of disease progression and treatment. BMC Med Inform Decis Mak. 2011;11:41.

44. Tangri N, Stevens LA, Griffith J, et al. A predictive model for progression of chronic kidney disease to kidney failure. JAMA. 2011;305(15):1553-1559.

45. Trivedi HS, Pang MM, Campbell A, Saab P. Slowing the progression of chronic renal failure: economic benefits and patients' perspectives. Am J Kidney Dis. 2002;39(4):721-729.

46. Feldman HI, Appel LJ, Chertow GM, et al; Chronic Renal Insufficiency Cohort (CRIC) Study Investigators. The Chronic Renal Insufficiency Cohort (CRIC) Study: Design and Methods. J Am Soc Nephrol. 2003;14(7 Suppl 2):S148-S153.

47. Chin HJ, Song YR, Lee JJ, et al. Moderately decreased renal function negatively affects the health-related quality of life among the elderly Korean population: a population-based study. Nephrol Dial Transplant 2008;23(9):2810-2817.
48. Gorodetskaya I, Zenios S, McCulloch CE, et al. Health-related quality of life and estimates of utility in chronic kidney disease. Kidney Int. 2005;68(6):2801-2808.

49. Krishnan AV, Kiernan MC. Neurological complications of chronic kidney disease. Nat Rev Neurol. 2009;5(10):542-551.

50. Molsted S, Prescott L, Heaf J, Eidemak I. Assessment and clinical aspects of health-related quality of life in dialysis patients and patients with chronic kidney disease. Nephron Clin Pract. 2007;106(1):c24-c33.

51. Mujais SK, Story K, Brouillette J, et al. Health-related quality of life in CKD Patients: correlates and evolution over time. Clin JAm Soc Nephrol. 2009;4(8):1293-1301.

52. Nulsen RS, Yaqoob MM, Mahon A, Stoby-Fields M, Kelly M, Varagunam M. Prevalence of cognitive impairment in patients attending pre-dialysis clinic. J Ren Care. 2008;34(3):121-126.

53. Porter A, Fischer MJ, Brooks D, et al. Quality of life and psychosocial factors in African Americans with hypertensive chronic kidney disease. Transl Res. 2012;159(1):4-11.

54. Richardson MM, Saris-Baglama RN, Anatchkova MD, et al. Patient experience of chronic kidney disease (CKD): results of a focus group study [abstract 175]. Am J Kidney Dis. 2007;49(4):B68.

55. Alexander M, Bradbury BD, Kewalramani R, Barlev A, Mohanty SA, Globe D. Chronic kidney disease and US healthcare resource utilization in a nationally representative sample. Am J Nephrol. 2009;29(5): 473-482.

56. Mix TC, St Peter WL, Ebben J, et al. Hospitalization during advancing chronic kidney disease. Am J Kidney Dis. 2003;42(5):972-981.

57. St Peter WL, Khan SS, Ebben JP, Pereira BJ, Collins AJ. Chronic kidney disease: the distribution of health care dollars. Kidney Int. 2004;66(1):313-321.

58. Vekeman F, Yameogo ND, Lefebvre P, Bailey RA, McKenzie RS, Piech CT. Healthcare costs associated with nephrology care in pre-dialysis chronic kidney disease patients. J Med Econ. 2010;13(4): 673-680.

59. Schneider KM, O'Donnell BE, Dean D. Prevalence of multiple chronic conditions in the United States' Medicare population. Health Qual Life Outcomes. 2009;7:82.

60. Amedia CA Jr. Managing chronic kidney disease. Manag Care. 2003; Spec No:8-12; discussion 17-20.

61. USRDS. Costs of chronic kidney disease. In: 2010 Annual Data Report. Volume One: Atlas of Chronic Kidney Disease in the United States [cited February 17, 2012]. Bethesda, MD: National Institutes of Health, National Institute of Diabetes and Digestive and Kidney Diseases; 2010. Available from: http://www.usrds.org/2010/pdf/V1_09.pdf. Accessed February 17, 2012.

62. Sullivan S. Employer challenges with the chronic kidney disease population. J Manag Care Pharm. 2007;13(9 Suppl D): S19-S21.

63. Papatheofanis F, Bookhart BK, Muser E, Piech CT. An examination of productivity and resource utilization associated with epoetin alfa treatment in employees with predialysis chronic kidney disease. $J$ Occup Environ Med. 2008;50(5):584-589.

64. Harshman R, Naim A, Carter J, Richerson G, Nair KV. Early detection, screening, and management of chronic kidney disease among actively employed - an integrated population health management approach [abstract PUK20]. Value Health. 2011;14(3):A78.

65. De Cosmo S, Lamacchia O, Rauseo A, et al. Cigarette smoking is associated with low glomerular filtration rate in male patients with type 2 diabetes. Diabetes Care. 2006;29(11):2467-2470.

66. Kramer H, Tuttle KR, Leehey D, et al. Obesity management in adults with CKD. Am J Kidney Dis. 2009;53(1):151-165.

67. Mafra D, Guebre-Egziabher F, Fouque D. Body mass index, muscle and fat in chronic kidney disease: questions about survival. Nephrol Dial Transplant. 2008;23(8):2461-2466.

68. Navaneethan SD, Yehnert H, Moustarah F, Schreiber MJ, Schauer PR, Beddhu S. Weight loss interventions in chronic kidney disease: a systematic review and meta-analysis. Clin JAm Soc Nephrol. 2009;4(10): $1565-1574$. 
69. Poortmans JR, Ouchinsky M. Glomerular filtration rate and albumin excretion after maximal exercise in aging sedentary and active men. J Gerontol A Biol Sci Med Sci. 2006;61(11):1181-1185.

70. Tuttle KR, Sunwold D, Kramer H. Can comprehensive lifestyle change alter the course of chronic kidney disease? Semin Nephrol. 2009;29(5):512-523.

71. Cabness J, Miller C, Flowers K. Promoting resilience in ESRD: evaluation of a group cognitive-behavioral intervention for patients on hemodialysis. J Nephrol Social Work. 2006;25:30-36.

72. Hoth KF, Christensen AJ, Ehlers SL, Raichle KA, Lawton WJ. A longitudinal examination of social support, agreeableness and depressive symptoms in chronic kidney disease. J Behav Med. 2007;30(1):69-76.

73. Kidney Disease Outcomes Quality Initiative (K/DOQI) Group. K/DOQI clinical practice guidelines for management of dyslipidemias in patients with kidney disease. Am J Kidney Dis. 2003;41:4(Suppl 3):I-IV, S1-91.

74. Brenner BM, Cooper ME, de Zeeuw D, et al; RENAAL Study Investigators. Effects of losartan on renal and cardiovascular outcomes in patients with type 2 diabetes and nephropathy. $N$ Engl $\mathrm{J} \mathrm{Med}$. 2001;345(12):861-869.

75. Randomised placebo-controlled trial of effect of ramipril on decline in glomerular filtration rate and risk of terminal renal failure in proteinuric, non-diabetic nephropathy. The GISEN Group (Gruppo Italiano di Studi Epidemiologici in Nefrologia). Lancet. 1997; 349(9069): 1857-1863.

76. Lewis EJ, Hunsicker LG, Bain RP, Rohde RD. The effect of angiotensinconverting-enzyme inhibition on diabetic nephropathy. The Collaborative Study Group. NEngl J Med. 1993;329(20):1456-1462. Erratum in: N Engl J Med. 1993;330(2):152.

77. Lewis EJ, Hunsicker LG, Clarke WR, et al; Collaborative Study Group. Renoprotective effect of the angiotensin-receptor antagonist irbesartan in patients with nephropathy due to type 2 diabetes. $N$ Engl J Med. 2001;345(12):851-860.

78. Maschio G, Alberti D, Janin G, et al. Effect of the angiotensinconverting-enzyme inhibitor benazepril on the progression of chronic renal insufficiency. The Angiotensin-Converting-Enzyme Inhibition in Progressive Renal Insufficiency Study Group. $N$ Engl J Med. 1996;334(15):939-945.

79. Ruggenenti P, Perna A, Gherardi G, et al. Renoprotective properties of ACE-inhibition in non-diabetic nephropathies with non-nephrotic proteinuria. Lancet. 1999;354(9176):359-364.

80. Parving HH, Andersen AR, Smidt UM, Svendsen PA. Early aggressive antihypertensive treatment reduces rate of decline in kidney function in diabetic nephropathy. Lancet. 1983;1(8335):1175-1179.

81. Jafar TH, Stark PC, Schmid CH, et al; AIPRD Study Group. Angiotensin-converting enzyme inhibition and progression of renal disease. Proteinuria as a modifiable risk factor for the progression of non-diabetic renal disease. Kidney Int. 2001;60(3):1131-1140.

82. Appel LJ, Wright JT Jr, Greene T, et al; African American Study of Kidney Disease and Hypertension Collaborative Research Group. Longterm effects of renin-angiotensin system-blocking therapy and a low blood pressure goal on progression of hypertensive chronic kidney disease in African Americans. Arch Intern Med. 2008;168(8):832-839.

83. Baigent $\mathrm{C}$, Landray $\mathrm{MJ}$, Reith $\mathrm{C}$, et al. SHARP Investigators. The effects of lowering LDL cholesterol with simvastatin plus ezetimibe in patients with chronic kidney disease (Study of Heart and Renal Protection): a randomised placebo-controlled trial. Lancet. 2011;377(9784):2181-2192.

84. The effect of intensive treatment of diabetes on the development and progression of long-term complications in insulin-dependent diabetes mellitus. The Diabetes Control and Complications Trial Research Group. N Engl J Med. 1993;329(14):977-986.

85. Writing Team for the Diabetes Control and Complications Trial/ Epidemiology of Diabetes Interventions and Complications Research Group. Sustained effect of intensive treatment of type 1 diabetes mellitus on development and progression of diabetic nephropathy: the Epidemiology of Diabetes Interventions and Complications (EDIC) study. JAMA. 2003;290(16):2159-2167.
86. Jenkins AJ, Lyons TJ, Zheng D, et al; DCCT/EDIC Research Group. Lipoproteins in the DCCT/EDIC cohort: associations with diabetic nephropathy. Kidney Int. 2003;64(3):817-828.

87. Levin SR, Coburn JW, Abraira C, et al. Effect of intensive glycemic control on microalbuminuria in type 2 diabetes. Veterans Affairs Cooperative Study on Glycemic Control and Complications in Type 2 Diabetes Feasibility Trial Investigators. Diabetes Care. 2000;23(10):1478-1485.

88. Hirsch S. An update on proteinuric chronic kidney disease: the dualgoal approach. Cleve Clin J Med. 2008;75(10):705-713.

89. Vilayur E, Harris DC. Emerging therapies for chronic kidney disease: what is their role? Nat Rev Nephrol. 2009;5(7):375-383.

90. Abbott. Positive results from phase 2 study of atrasentan for treatment of diabetic kidney disease published in the Journal of the American Society of Nephrology [press release]. Abbott Park, IL: Abbott; 2011 [Mar 4]. Available from: http://www.abbott.com/news-media/pressreleases/2011Mar04.htm. Accessed February 17, 2012.

91. Reata Pharmaceuticals. Bardoxolone methyl [web page on the Internet]. Irving, TX: Reata Pharmaceuticals; nd. Available from: http://www. reatapharma.com/pip_rta402.asp. Accessed February 17, 2012.

92. Mitsubishi Tanabe Pharma Corporation. A study of AST-120 for evaluating prevention of progression in chronic kidney disease (EPPIC-1). In: ClinicalTrials.gov [website on the Internet]. Bethseda, MD: US National Library of Medicine; 2007 [updated October 1, 2012]. Available from: http://clinicaltrials.gov/ct2/show/NCT00500682? term=ast-120\&rank=7. NLM identifier: NCT00500682. Accessed October 1, 2012.

93. Abbott. A prospective, double-blind, placebo-controlled, multicenter study to evaluate efficacy and safety of atrasentan, including thoracic bioimpedance, in type 2 diabetic subjects with nephropathy. In: ClinicalTrials.gov [website on the Internet]. Bethseda, MD: US National Library of Medicine; 2011 [updated August 11, 2012]. Available from: http://clinicaltrials.gov/ct2/show/NCT01399580 ?term=atrasentan+and+kidney+disease $\&$ rank=3. NLM identifier: NCT01399580. Accessed October 1, 2012.

94. Kureha. Business Report 2010. Tokyo: Kureha; 2010. Available from: http:// www.kureha.co.jp/en/ir/pdf/br2010.pdf. Accessed February 17, 2012.

95. Mitsubishi Tanabe Pharma Corporation. A study of AST-120 for evaluating prevention of progression in chronic kidney disease including assessment of quality of life (EPPIC-2). In: Clinical Trials.gov [website on the Internet]. Bethseda, MD: US National Library of Medicine; 2007 [updated October 1, 2012]. Available from: http:/clinicaltrials.gov/ct2/show/NCT00501046?term=AST120\&rank=8. NLM identifier: NCT00501046. Accessed October 1, 2012.

96. Concert Pharmaceuticals. CTP-499 - first-in-class treatment candidate for diabetic nephropathy. In: Technology [web page on the Internet]. Lexington, MA: Concert Pharmaceuticals; nd. Available from: http:// www.concertpharma.com/research/index.html\#CTP499. Accessed February 17, 2012.

97. Vitae Pharmaceuticals. VTP-27999 program. In: Direct inhibition of renin offers potentially better renal protection than current therapies for the 27 million people worldwide with chronic kidney disease (CKD) [web page on the Internet]. Fort Washington, PA: Vitae Pharmaceuticals; nd. Available from: http:/www.vitaepharma.com/view.cfm/56/ Chronic-Kidney-Disease-Renin. Accessed February 17, 2012.

98. Novartis. Novartis announces termination of ALTITUDE study with Rasilez $^{\mathbb{B}} /$ Tekturna $^{\circledR}$ in high-risk patients with diabetes and renal impairment [media release]. Basel: Novartis; 2011 [Dec 20]. Available from: http://www.novartis.com/newsroom/media-releases/en/2011/1572562. shtml. Accessed February 17, 2012.

99. Taal MW, Brenner BM. Predicting initiation and progression of chronic kidney disease: Developing renal risk scores. Kidney Int. 2006;70(10):1694-1705.

100. Levey AS, Eckardt KU, Tsukamoto Y, et al. Definition and classification of chronic kidney disease: a position statement from Kidney Disease: Improving Global Outcomes (KDIGO). Kidney Int. 2005;67(6):2089-2100. 
International Journal of Nephrology and Renovascular Disease

Dovepress

\section{Publish your work in this journal}

The International Journal of Nephrology and Renovascular Disease is an international, peer-reviewed open-access journal focusing on the pathophysiology of the kidney and vascular supply. Epidemiology, screening, diagnosis, and treatment interventions are covered as well as basic science, biochemical and immunological studies. The journal welcomes

original research, clinical studies, reviews \& evaluations, expert opinion and commentary, case reports and extended reports. The manuscript management system is completely online and includes a very quick and fair peerreview system, which is all easy to use. Visit http://www.dovepress.com/ testimonials.php to read real quotes from published authors.

Submit your manuscript here: http://www.dovepress.com/international-journal-of-nephrology-and-renovascular-disease-journal 